\title{
Impact of Nongovernmental Micro Finance Programs on Poverty Alleviation in Sri Lanka
}

\author{
J.A.Prasansha Kumari \\ Senior Lecturer, Department of Economics, University of Kelaniya, Sri Lanka
}

\begin{abstract}
Microfinance is the widely used throughout the world for many decades. Over the past ten years micro finance programs have spread quickly across the country as a main tool of alleviating poverty. This is an ongoing research and it aim to analyses the impact of micro financial programs for reducing the poverty level with special reference to Sarvodya Economic Eunterpernerships Services (SEEDS). Information and primary data will be collected throughout structured questioner and interviews from 200 beneficiaries in Kegalle district. Secondary data will be collected from annual reports, books, web sites and other relevant documents. Main expected outcomes are the program will be effectively impact to generate new income opportunities, savings, investment and consumption while economically and socially empowering the poor people
\end{abstract}

Keywords: Nongovernmental organization, micro finance, poverty, saving, investment

\section{Introduction}

Sri Lanka being a developing country has been trying various ways and means to achieve development and bring prosperity to its people. Poverty has been identified as a serious socio-economic issue to overcome when the nation march towards the development and prosperity. There are four sector of poverty as rural, urban, costal and plantation. According to the Central Bank of Sri Lanka, overall poverty rate in Sri Lanka is 8.9 percent in 2013/2014. In the same year, the highest rate of poverty has been reported in the District of Battcloa (20.3 percent). where the majority of the population is plantation workers. Monaragala district, which is inhabited by plantation workers as well as poor small farmers, has a poverty rate of 29 percent. Many districts of Sri Lanka have a poverty rate above 18 percent. One instrument that the policy makers are seriously advocating in the process of poverty alleviation and bringing less developed areas in the country to the path of development is the microfinance mechanisms. Microfinance is considered as a tool that could be used to influence directly or indirectly each dimension of the poverty. Microfinance, as per the Asian Development Bank (ADB), is the provision of a broad range of financial services such as; deposits, loans, payment services, money transfers insurance to poor and low-income households and their microenterprises.

Microfinance is the widely used throughout the world for many decades as a tool to alleviate poverty. In fact, due to its significance and outreach in the alleviation of poverty the United Nations declared the year 2005 as International Year of Microcredit with the aim of "Building Inclusive Financial Sectors to achieve Millennium Development Goals". Former Secretary General of United Nations, Mr. Kofi Annan in issuing a message to the International Year of Microcredit had said; "Microfinance has proved its value, in many countries, as a weapon against poverty and hunger. It really can change peoples' lives for the better -- especially the lives of those who need it most. Let us be clear: microfinance is not charity. It is a way to extend the same rights and services to low-income households that are available to everyone else. It is recognition that poor people are the solution, not the problem. It is a way to build on their ideas, energy, and vision. It is a way to grow productive enterprises, and so allow communities to prosper."

Micro finance programmes have rapidly spread worldwide on the premise that they help to eradicate poverty and create economic growth and the resulting literature is now very large. The popular press has waved the banner of microfinance as perhaps the most important recent tool to reduce poverty (Francisco Examiner1990, 1999; The Economist 1993; Malveaux 1997; and New York Times 1997). The 1997 MicrocreditSummit called for the mobilization of $\$ 20$ billion over a 10-year period to support microfinance (Microcredit Summit Report 1997) Some study claim that micro- loans can greatly improve the welfare of the poor (McKernan, 2002) Pitt and Khandker (1998) use the eligibility threshold for getting loan from Grameen Bank as source of identifying variation in a structural model of the impact of micro credit and find large positive effect, especially for women. Recent evidences suggests that integrating business training into micro finance programmes can improve their effectiveness and pay for it self (Karlan and Waldivia,2006)The Economics literature of micro finance is inconclusive some study claim that micro- finance can greatly improve the income of the poor while other suggest that the impact of such programme is exaggerated because of self- selection and endogenous programme placement (Coleman, 1999). 


\section{Micro Finance in Sri Lanka}

Since independence, successive Sri Lankan Governments have launched several microfinance programme for poverty alleviation programs which include the establishment of Thrift and Credit Cooperative Societies, Janasaviya program, National Development Fund and recently the Samurdhi program. Samurdhi is currently the national poverty alleviation programme which began its operations in August 1994 and in operation as of to date. The Government Samurdhi Savings and Credit scheme that was established in 1996 as a part of the Samurdhi program is one of the largest microcredit and social mobilization programs in Sri Lanka. Samurdhi scheme has about over 32,000 village level societies and over 1000 bank branches operating all over Sri Lanka.

Large number of governmental organizations have involved in providing microfinance facilities in Sri Lanka, their effectiveness and impact on empowering people and reducing poverty. However, detailed research studies have been much more guarded about their impact. In particular, several studies have raised doubts about the effectiveness of MFIs in reaching the "core poor" in the Asian countries.(Montgomery.H and Weiss.J,2005). Some studies that have been carried out in this area are mainly confined to the Government microcredit institutions or programs such as Janasaviya and Samurdhi. Many of the poverty related researchers have identified that Government poverty alleviation programs have always been hindered by political patronage and misallocation of the resources (CEPA, 2009)

According to (Adams et al.1984, Adams and Vogel 1986, World Bank 1989), efforts to deliver formal credit and financial services to the rural poor in developing countries, like Sri Lanka have failed. Commercial banks generally do not serve the needs of the rural poor because of the perceived high risk and the high transaction costs associated with small loans and savings deposits. To fill the void, many governments have tried to deliver formal credit to rural areas by setting up special agricultural banks or directing commercial banks to loan to rural borrowers. However, these programs have almost all failed because of the political difficulty for governments to enforce loan repayment, and because the relatively wealthy and powerful, rather than the poor, received most of the loans. Therefore, the microfinance schemes have implemented by the Non-Governmental organizations in the poorest areas in developing countries. Currently, there are several non governmental organizations in Sri Lanka that are involved in providing microcredit facilities to the low income earning sections of the society. They include Cooperative Societies, local and international Non-Governmental Organizations, private commercial banks, Development banks. SEEDS and Agro micro finance programmes were the largest NGO_MFI in the country.

Over the past ten years those micro finance programmes have spread quickly across the country, but there are very few studies that have evaluated their impact (effectiveness and implications) on the alleviation of poverty and empowering people is currently an important lacuna to fill and hence be extremely useful and beneficial to the socio-economic policy makers, academics and students alike.

\section{Problem of the Study}

What is the impact of Non Government's Micro Finance Programmes for poverty alleviation in Sri Lanka?: As a developing county, poverty is serious issues of Sri Lanka. Government and Non Government Organization of the country are lunching poverty alleviation progammes in the country. During the period of last two -three decades, worldwide microfinance institutions have operated several programmes in Sri Lanka. Most of them are providing micro services towards the poor and their main goal of microfinance give low income people an opportunity to become self-sufficient by providing a means of saving money, borrowing money and insurance. In order to the research problem is based on identifying the impact of those Non Government Micro Finance Programmes for alleviating poverty in the country.

\section{Objectives of the study}

Identify the impacts of micro finance programmes for alleviating poverty in Sri Lanka with special reference to the Non Government Micro Finance Porgrammes The Government of Sri Lanka has launched several national poverty alleviating programmes after liberalization period such as janasawiya, targeted food stamp programme, sammurdhi programme. According to Centre for Poverty Analysis (CEPA) those programmes have been hindered by political patronage and misallocation of resources. It said there was an inconsistent approach to poverty. "The lack of a consistent poverty reduction strategy at national level over the past few decades has meant that the improved performance in the economy has not contributed to employment generation and human development in several groups,"(CEAP,2009) Non Governmental Organization poverty alleviating programmes are another way to reduce the poverty without political patronage and misallocation of recourse . The main purpose of this research is identify the impact NGO's micro finance programmes on poverty alleviation of the country. 


\section{Methodology of the Research}

This research conducted a total of 200 households in 05 "treatment"villages in Kegalle 5 of the villages were supported by SEEDS micro finance. Statured questionnaires and interviews used to collect primary data from target groups. Secondary data gathered from relevant publication such as books, magazines, annual reports, news papers, web sites and other relevant research documents. Collected data analyzed by using descriptive research methods.

\section{Expected Outcomes}

SEEDS credit banks providing three types of financial assistance to the low income households in the area as shown in table I. Table II represent the further details about credit information in the studies area,

Table:1 Micro Credit Scheme of SEEDS

\begin{tabular}{|lrr|}
\hline Category & Purpose & Amount RS \\
\hline A & Income generate project & $10,000-50,000$ \\
B & Basic needs of low incomers & $10,000-50,000$ \\
C & New employment generate project & $50,000-500,000$ \\
\hline
\end{tabular}

Source: SEEDS, 2009

This research is in an ongoing state, according to the observation and collected information so far it was revealed that SEED micro finance program impacted on create small scale eunterpernerships and new job opportunities. Micro credit program effectively used by browsers to create new income generation project such as retail services, handy craft, farming, batik making, beauty flaring , dress making etc. In addition, micro finance services which provided by the SEEDs directly promoted to economic empowerment of the poor people in the area. It provide wide range of financial and non-financial services to grassroots level people. SEEDS banking society provide different types of saving opportunities to develop the saving habits of generators. The research found that saving amounts and investment had increased as SEEDS group saving opportunities. Moreover, consumption level and types of consumption goods and services have changed as the increase of income level of households. Non financial services such as advises on financial management, skill development training were influenced to develop their soft skills and ability for economic empowering.

\section{Conclusion}

According to so far observation, the research identity that nongovernmental micro credit programs have a steady assessment to monitoring the effectiveness of the program. SEEDS microfinance program impacted on increased the household income, saving, investment and consumption level while it providing different types of training programs and insurance scheme. However, dependency syndromes of poor people in the area is a main obstacle to reducing poverty level in low incomer's.

\section{References}

[1]. Amin, S., Rai, A.S., \& Topa, G (2003). Does Microcredit reach the Poor and Vulnerable?, Evidence from Northern Bangladesh,2 Journal of Development Economics.

[2]. Anhijit Banerjee, Esther Duflo, Rachel Glennerster, Cynthia Kinnan (2010), The Miracle of Microfinance? Evidence from a Randomized Evaluation, Center for Microfinance, Hyderabad, India

[3]. Asian Development Bank(1997), Asian Development Bank Report

[4]. Brau, J.C., \& Woller, G. M(2004). Microfinance: A Comprehensive Review of the Existing Literature, Journal of Entrepreneurial Finance and Business Ventures,

[5]. Brett E.Coleman(2002),“ The impact of Group Lending in Northeast Thailand, Journal of Development Economics 60 (1999).

[6]. Brett. Coleman(2002), Microfinance in Northeast Thailand: Who benefited and how much? Asian Development Bank, ERD working paper series No 9 .

[7]. Central Bank of Sri Lanka (2009), Central Bank Report Janadipathi Mw, Colombo

[8]. Copestake, J., Bhalotra,S., Johnson, s.(2001), Assessing the Impact of Micro credit: A Zambian Case Study, Journal of Development Studies.

[9]. Evans, T.G.Adams, A.M. (1999), Demystifying Nonparticipation in Microcredit: A Population- Based Analysis. World Development, 27(2)

[10]. Jonathan Morduch, (2002), Analysis of the Effects of Microfinance on Poverty Reduction, NYU Wagner Working Paper No. 1014,Robert F. Wagner Graduate, School of Public Service, New York University4 Washington Square North, New York

[11]. Judith Shaw, Microenterprise Occupation and Poverty Reduction in Microfinance Programs: Evidence from Sri Lanka,(2004), RMIT University, Victoria, Australia

[12]. Justin Bucciferro(2010), Microfinance Impact in Chile: A Tale of Two ZCooperatives, Department of Economics, Universitry of Colorado, Boulder.

[13]. Kabeer, N (2001). Conflicts over Credit": Re-evaluating the Empowerment potential of Loan to Women in Rural Bangladesh, World Development

[14]. Karlan, Dean and Jonathan Zinman(2006). “Credit Elasticities in Less Developed Economics: implications for microfinance. 
[15]. McKernan, Signe-Maey. (2002) “The impact of microcredit: Programmes on Self- Employment Profits: Do noncredit Programme Aspects Matter, Review of Economics and Statistic.

[16]. Micro credit and empowerment: A study of Kudumbashree project in Kerala, India (2009) Journal of Rural Development, Vol. 28, No. (4), pp. 469 - 484, NIRD, Hyderabad.

[17]. Mohammed Emrul hasan, Microfinance with Un-reached people in the rural area: Experience and learning, Program Specialist, Family Economic Security Program Plan International Bangladesh, Bangladesh.

[18]. Monique Iglebaek BRAC as Researcher. Microfinance for the Extreme Poor (Working Paper) Plan Bangladesh, Bangladesh

[19]. Montgomery.H and Weiss.J,2005, Great Expectation: Microfinance and Poverty Reduction in Asia and Latin America, Research paper series No 63, Asian Development Banka.

[20]. Nitin Bhatt, Shui-Yan Tang; 2001, "Delivering Microfinance in Developing Countries, Controversies and Policy Perspectives, Policy Studies Journal, Volume: 29. Issue: 2.

[21]. Okurut Francis Nathan,Banga Margaret,MukunguAshie,(2004), Micro Finance and poverty reduction in Uganda: Achievements and challenges, , Research series No 41, economic policy Research center, 51 pool Road, Makerere University campus, Kampala, Uganda.

[22]. Park A (2001) microfinance with Chinese characteristics, World Development

[23]. Pitt, Mark M . and Shahidur R. Khandker. (1998)“"The Impact of group- Based credit programmes on poor households in Bangladesh": Does the Gender of Participant Matter" Journal of Political Economy.

[24]. Sam .D.H (edt) 2002, "Pathway out of Poverty: innovations in Micro Finance for the Poorest Families", Kumarian Press. Bloomfield, CT.

[25]. Shehery Banuri (2006), Impact of Microfinance on Poverty, Income Inequality and Entrepreneurship, School of Economics, Political and Policy, Texas

[26]. T. M. Kudi S. B. Odugbo, A. L. Banta and M. B. Hassan(2009) Impact of UNDP Microfinance Programme on Poverty Alleviation among Farmers in Selected local Government Areas of Kaduna State, Nigeria, Department of Agricultural Economics and Rural Sociology, Faculty of Agriculture Ahmadu Bello University, Zaria.

[27]. Tilakaratna, G., A. Galappattige and T. Kumara (2006) 'Annotated Bibliography on Microfinance in Sri Lanka', Poverty and Social Welfare Series No. 8, Institute of Policy Studies of Sri Lanka, Colombo, Sri Lanka. 